\title{
Triiodothyronine and thyroxine changes in yearling sea trout (Salmo trutta L.) during spring
}

\author{
Ilze Rutkovska, Ruta Medne
}

Received - 29 December 2017/Accepted - 12 June 2018. Published online: 30 June 2018; @Inland Fisheries Institute in Olsztyn, Poland Citation: Rutkovska I., Medne R. 2018 - Triiodothyronine and thyroxine changes in yearling sea trout (Salmo trutta L.) during spring - Fish. Aquat. Life 26: 101-109

\begin{abstract}
Triiodothyronine and thyroxine levels and morphological parameters of fish were studied from January to May to evaluate the smoltification of yearling sea trout (Salmo trutta L.) raised in two different rearing systems (recirculating and flow-through) in three different hatcheries in Latvia. Thyroid hormone levels increased from January to May in both rearing systems in fish of different sizes. There was positive correlation between the degree of silvering and fish fork length and thyroid hormone levels, but there was no correlation between condition facor and thyroid hormone levels. Fish reared in recirculating systems were significantly larger $(p<0.05)$ and exhibited more visible signs of smoltification earlier than those reared in flow-through systems. The thyroid hormone levels and degree of silvering gradually became nearly the same by May in the sea trout from both rearing systems. Changes in thyroid hormone levels or fish size in spring cannot be evaluated separately from other signs to determine smoltification.
\end{abstract}

Keywords: morphology, salmonids, silvering, smoltification, thyroid hormones.

I. Rutkovska [ $\left.\Xi^{\circ}\right]$, R. Medne

Latvia University of Life Sciences and Technologies,

Faculty of Veterinary Medicine, Latvia

e-mail: ilze.rutkovska@gmail.com

Ruta Medne

Institute of Food Safety, Animal Health and Environment BIOR, Latvia

\section{Introduction}

The aim of sea trout (Salmo trutta L.) stocking in Latvia is to improve natural salmonid resources mainly to compensate for the negative effects of the hydroelectric power station cascade on the Daugava River and for other anthropogenic factors. It is insufficient to release certain amount of fish into natural watercourses; the fish released should be mature enough to achieve the highest possible stocking effectiveness. In Latvian climatic conditions wild sea trout start to migrate to the sea at the end of April; the highest migration levels are in the first part of May, and migration is usually finished by the end of May (Birzaks et al. 1997).

Smoltification is a crucial metabolic process in anadromous salmonids that includes neuroendocrine, physiological, and behavioral changes enabling juvenile salmonid parr to adapt from fresh to salt water (McCormick 2013). Although all endocrine glands take part in smoltification, some researchers contend that the most important role is played by the thyroid gland (Holzer and Laudet 2015). Reports indicate increases in the levels of plasma thyroxine, triiodothyronine, cortisol, growth hormone, insulin-like growth factor, and other hormones are noted during smoltification (McCormick and Björnsson 1994, Björnsson et al. 2011). Thyroid

(c) Copyright by Stanisław Sakowicz Inland Fisheries Institute in Olsztyn.

(c) 2018 Author(s). This is an open access article licensed under the Creative Commons Attribution-NonCommercial-NoDerivs License (http://creativecommons.org/licenses/by-nc-nd/3.0/). 
hormones affect growth, morphogenesis, skin pigmentation, the ability to osmoregulate, and behavior during smoltification (Hoar 1988). The disappearance of melanin and the deposition of guanine is connected with elevated thyroid hormone activity (Hoar 1988). It appears that the development of thyroid hormones is a cyclical process that culminates in spring in some species while in fall in others (Osborn et al. 1978). The highest thyroxine (T4) levels coincide with smoltification in spring. In coho salmon (Oncorhynchus kisutch) high T4 levels persist for 30 to 60 days and moderately impact morphological parameters (Dickhoff et al. 1978).

Thyroid hormones are connected with behavioral changes such as salt-water resistance (Soivio et al.1989), migration to seas (McCormick 2013, Zydlewski et al. 2014), and changes in swimming activity (Katz and Katz 1978). Smolt migration is associated with elevated thyroid hormone levels (Hoar 1988). However, some authors (Ojima and Iwata 2009) express the opinion that smolt migration is not caused by increased thyroid hormones, but rather that migration increases thyroid hormone levels. Estimating thyroxine levels in salmonids is used as an indicator of smoltification (Folmar and Dickhoff 1980). In salmonid smolts, extended photoperiods are accompanied by elevated plasma $\mathrm{T} 4$ that exceeds T4 levels in Atlantic salmon in natural day lengths (McCormick et al. 1995, Zydlewski et al. 2014). At the same time, Ebbesson et al. (2008) notes the significance of thyroid hormone participation in the mechanism of the light-brain-pituitary axis. Changes in brain structure, neurotransmitters, and receptors are noted before thyroid hormone levels increase (Ebbesson et al. 2003). Ebbesson et al. (2011) report that corticotropin-releasing factor (CRF) neurogenesis is regulated by thyroid hormones at the end of smoltification. The structural transformation of fish brains is seen before any increase in thyroid hormone levels (Ebbesson et al. 2003, 2011). For most teleosts, hypophysectomy precludes long-term habitation in salt water (Griffith 1974).

Until now in Latvia, smoltification has been determined only by fish weight, i.e., fish of $15 \mathrm{~g}$ at the time of release in April or May are considered to be smolts. Other parameters are not taken into account. Additionally, there is an insufficient number of studies about sea trout growth, development, and smoltification under Latvian environmental conditions. That a sea trout weight of $15 \mathrm{~g}$ is deemed the appropriate size threshold is based on theoretical presumptions and not on scientific fact. The aim of this study was to determine changes in thyroid hormone levels in yearling sea trout reared in Latvia during spring and to determine whether these changes can be used as evidence of smoltification.

\section{Materials and methods}

The study was conducted at the Latvia University of Life Sciences and Technologies, Faculty of Veterinary Medicine, Institute of Food and Environmental Hygiene and the Institute of Food Safety, Animal Health and Environment BIOR, Laboratory of Aquaculture and Fish Pathology. During the study, different sized sea trout (6.3-30.6 g size range) were examined. A total of 386 yearling sea trout were obtained from hatcheries located in three separate Latvian river basins: hatchery A (Venta River basin), hatchery B (Gauja River basin), and hatchery C (Daugava River basin). The fish were reared in flow-through systems at all the hatcheries, but in hatchery $\mathrm{C}$ they were also reared in recirculating systems (CR). The fish were kept in ambient river water in tanks with a $1.5 \mathrm{~m}$ diameter under a natural photoperiod. The water flow rate was $0.16-0.18 \mathrm{~m}$ $\mathrm{sec}^{-1}$. Stocking density in all hatcheries was approximately $30 \mathrm{~kg} \mathrm{~m}^{-3}$. The fish were fed commercial pelleted feed (Aller Futura, Aller Aqua) of an appropriate size and in quantities recommended by the manufacturer. Oxygen levels and water temperatures were measured three times daily at 08:00, 14:00, and 20:00. The oxygen level throughout the rearing period was $7-10 \mathrm{mg} \mathrm{L}^{-1}$, and if it decreased to $7 \mathrm{mg} \mathrm{L}^{-1}$, additional oxygen was provided by oxygen pumps. 
Blood samples from 7-8 randomly sampled fish from each hatchery were drawn from the caudal vein once every two weeks from January to February, once a week in March and April, and once at the beginning of May before the sea trout were released. Plasma samples were frozen at $-18^{\circ} \mathrm{C}$ immediately and stored frozen until they were sent to laboratory (E. Gulbja Laboratorija, Latvia) for determinations of thyroxine (T4) and triiodothyronine (T3) concentrations with the immunochemical luminescence method. ADVIA Centaur XP Siemens Healthcare Diagnostics Immunoassay System was used for hormonal analysis (reagents - ADVIA Centaur T4, T3/T4/VB12 Ancillary Reagent, T4 Diluent and ADVIA Centaur T3, T3/T4/VB12 Ancillary Reagent, T3 Diluent).

After blood sampling, sea trout silvering was evaluated using a scale from 0 to 4 (Birt and Green 1986, modified by Rutkovska and Medne 2015) (Table 1), fish fork length was measured, and the fish were weighed. In May, fish of the appropriate weight ( $\geq 15 \mathrm{~g}$ ) were released into the natural environment.

Condition factor (CF) was calculated with the following formula (Formula 1) (Berrill et al. 2006):

$$
C F=\frac{W}{L^{3}} \times 100
$$

where,

CF - condition factor;

$\mathrm{W}$ - fish weight $(\mathrm{g})$;

$\mathrm{L}$ - fork length (cm).

Silvering indices were calculated with the following formula (Formula 2) (Medne 2011):

$$
I_{s}=N^{-1} \sum_{n=0}^{5} n_{i} S
$$

where,

$\mathrm{I}_{\mathrm{S}}$ - silvering index of fish group;

$\mathrm{N}$ - number of fish examined;

$\mathrm{n}$ - number of fish in each silvering group;

$\mathrm{S}$ - degree of silvering according to the scale (Table 1).

Means and standard error (SE) were calculated for the data obtained. Changes in parameters from
Table 1

Evaluation of the degree of silvering in yearling sea trout $(S$. trutta)

\begin{tabular}{ll}
\hline Scale & Description \\
\hline \hline 0 & Parr. No signs of silvering, clearly visible parr marks \\
1 & $\begin{array}{l}\text { Parr. Slightly silvery colour. Visible parr marks, some } \\
\text { signs of silvering }\end{array}$ \\
& $\begin{array}{l}\text { Smolt-like parr. (50\% silvering). Silvery color and } \\
\text { visible parr marks }\end{array}$ \\
& $\begin{array}{l}\text { Smolt-like parr. (75\% silvering). Silvery color and only } \\
\text { slightly visible parr marks }\end{array}$ \\
& $\begin{array}{l}\text { Smolt. Silvery colour, black fin margins. No visible } \\
\text { parr marks }\end{array}$ \\
\hline \hline
\end{tabular}

month to month, differences among hatcheries located on the different rivers, and the differences between the flow-through and recirculating systems in hatchery $\mathrm{C}$ were compared with the T-test for comparing two separate samples (Sokal and Rohlf 2000). Parametric tests were used since variances were homogeneous and distribution was normal. ANOVA was used to test differences among parameters. Differences among groups were considered statistically significant at $\mathrm{P}<0.05$.

\section{Results}

The water temperature data obtained from the hatcheries indicated that at the beginning of the study the water temperatures in the flow-through systems were almost equal, to but significantly lower than those in the recirculating systems (Fig. 1). At the time the fish were released, the water temperatures in the flow-through systems reached the levels of those in the recirculating systems and even exceeded them in hatcheries A and C. Yearling sea trout weight was $15.3 \pm 4.62 \mathrm{~g}$ (from 6.29 to $19.0 \mathrm{~g}$ ) in the flow-through systems and $25.6 \pm 7.25 \mathrm{~g}$ (from 13.1 to $47.7 \mathrm{~g}$ ) in the recirculating systems. Fork length was $11.1 \pm 1.1 \mathrm{~cm}$ (from 8.3 to $14.0 \mathrm{~cm}$ ) in the 


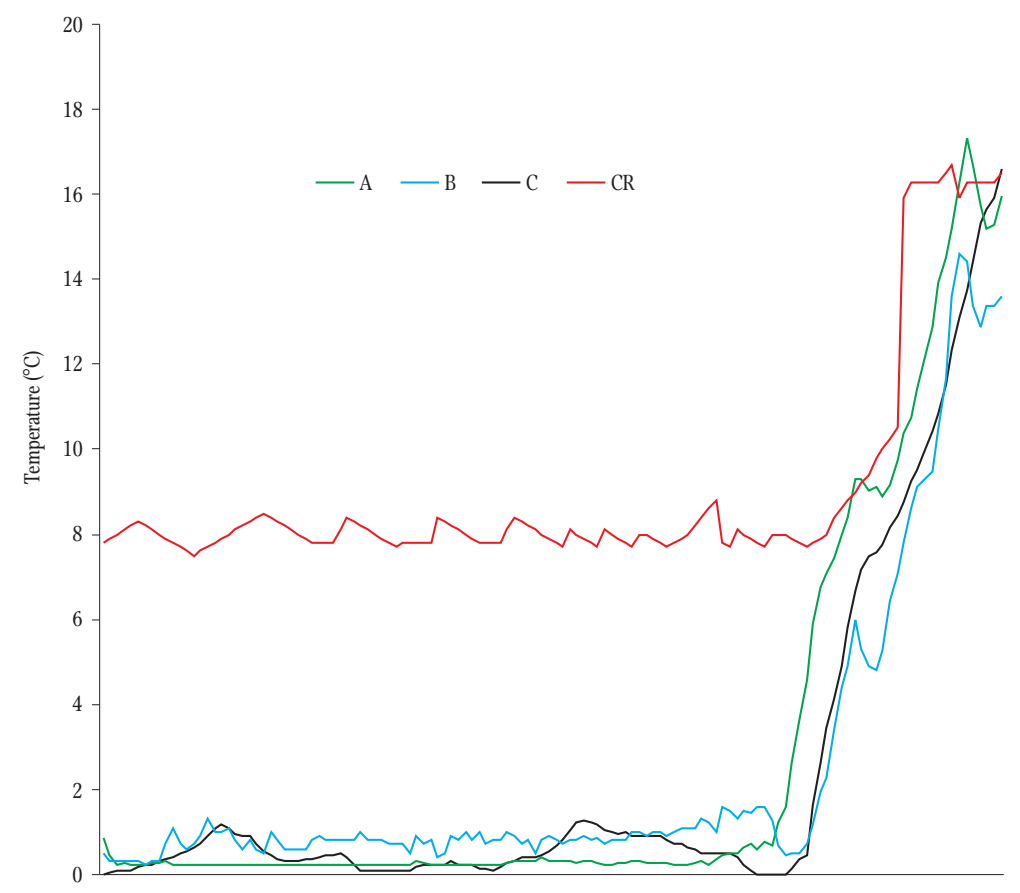

Figure 1. Seasonal changes of temperature in hatcheries. A - Venta River basin, B - Gauja River basin, C - Daugava River basin, CR recirculation system

flow-through systems and $12.62 \pm 1.22 \mathrm{~cm}$ (from 10.0 to $15.5 \mathrm{~cm}$ ) in the recirculating systems. CF was $1.10 \pm 0.11$ (from 0.84 to 1.54 ) in the flow-through systems and $1.24 \pm 0.11$ (from 1.04 to 1.50 ) in the recirculating systems. At all the hatcheries, the degree of silvering increased slightly during the spring, but it did not reach the maximum degree of 4 in the flow-through systems, and just a few individuals silvered completely in the recirculating systems (Table 2). The degree of silvering in the recirculating systems was significantly higher $(\mathrm{P}<0.05)$ than in the flow-through systems in January, but the difference decreased gradually. The $\mathrm{CF}$ of all degrees of silvering was almost equal (1.10-1.12) in the flow-through systems. However, the average values of the other parameters increased with the degree of silvering (Table 3). No sea trout exhibited degrees of silvering of 0 or 1 in the recirculating systems, and the mean $\mathrm{CF}$ was nearly equal for all degrees of silvering in the recirculating systems. However, the average values of the other parameters together with the degree of silvering raised the level of this in the flow-through systems (Table 3).

Table 2

Mean values of silvering index in yearling sea trout (S. trutta) in spring

\begin{tabular}{llllll}
\hline \hline & \multicolumn{1}{l}{ Month } & & & & \\
\cline { 2 - 5 } Fish farm/ rearing system & January & February & March & April & May \\
\hline \hline A/ flow-through & 0.94 & 1.65 & 2.55 & 2.55 & 2.85 \\
B/ flow-through & 1.43 & $2.50^{\mathrm{a}}$ & $2.63^{\mathrm{a}}$ & 2.81 & $2.67^{\mathrm{a}}$ \\
C/ flow-through & $1.44^{\mathrm{c}}$ & $1.71^{\mathrm{c}}$ & $2.38^{\mathrm{a}}$ & $2.73^{\mathrm{b}}$ & 3.00 \\
C/ recirculation & $2.07^{\mathrm{c}}$ & $2.10^{\mathrm{c}}$ & $2.86^{\mathrm{a}}$ & 2.95 & 3.00 \\
\hline \hline
\end{tabular}

asignificant difference $\mathrm{P}<0.01$ in comparison with previous month

${ }^{\mathrm{b}}$ significant difference $\mathrm{P}<0.05$ in comparison with previous month

${ }^{\mathrm{c}}$ significant difference $\mathrm{P}<0.05$ between rearing systems of hatchery $\mathrm{C}$ 
Table 3

Mean $( \pm \mathrm{SE})$ body weight $(\mathrm{g})$, fork length $(\mathrm{cm})$, condition factor $(\mathrm{CF})$, triiodothyronine $\left(\mathrm{T} 3, \mathrm{nmol} \mathrm{L}^{-1}\right)$ and thyroxine $\left(\mathrm{T} 4, \mathrm{nmol} \mathrm{L}^{-1}\right)$ for different silvering levels in yearling sea trout (S. trutta) in spring

\begin{tabular}{lllllll}
\hline \hline Rearing system & Silvering level & Body weight & Fork length & CF & T3 & T4 \\
\hline \hline Flow-through & 0 & $9.03 \pm 2.82$ & $9.25 \pm 0.85$ & $1.11 \pm 0.05$ & $1.70 \pm 0.5$ & $13.00 \pm 4.11$ \\
& 1 & $13.67 \pm 3.87^{\mathrm{b}}$ & $10.60 \pm 1.02^{\mathrm{b}}$ & $1.12 \pm 0.13$ & $1.93 \pm 0.58$ & $16.86 \pm 6.77$ \\
& 2 & $13.49 \pm 3.32$ & $10.66 \pm 0.81^{\mathrm{a}}$ & $1.10 \pm 0.12^{\mathrm{a}}$ & $2.08 \pm 0.55$ & $29.69 \pm 12.49^{\mathrm{b}}$ \\
& 3 & $17.43 \pm 4.81^{\mathrm{a}, \mathrm{b}}$ & $11.57 \pm 1.07^{\mathrm{a}}$ & $1.10 \pm 0.10^{\mathrm{a}}$ & $2.77 \pm 0.84^{\mathrm{b}}$ & $35.63 \pm 17.76^{\mathrm{a}, \mathrm{b}}$ \\
& 4 & - & - & - & - & - \\
Recirculation system & - & - & - & - & - \\
& 1 & - & - & & - & - \\
& 2 & $23.18 \pm 6.17$ & $12.29 \pm 1.19^{\mathrm{a}}$ & $1.23 \pm 0.11^{\mathrm{a}}$ & $2.17 \pm 0.69$ & $16.45 \pm 12.68$ \\
& 3 & $26.85 \pm 7.63^{\mathrm{a}}$ & $12.79 \pm 1.20^{\mathrm{a}}$ & $1.26 \pm 0.11^{\mathrm{a}}$ & $2.66 \pm 0.47$ & $32.76 \pm 12.66^{\mathrm{a}, \mathrm{b}}$ \\
& 4 & $34.26 \pm 4.30$ & $14.10 \pm 1.27$ & $1.23 \pm 0.18$ & $3.01 \pm 0.33$ & $45.03 \pm 8.42$ \\
\hline \hline
\end{tabular}

${ }^{\text {a }}$ significant difference $\mathrm{P}<0.01$ in comparison with recirculating systems/flow-through systems

bsignificant difference $\mathrm{P}<0.05$ in comparison with previous month

T3 levels of the fish reared in flow-through systems decreased from January to February, but then they started to increase in all three hatcheries (Fig. 2). The highest T3 levels in hatcheries $\mathrm{A}$ and $\mathrm{B}$ were noted in April at 3.14 and $2.66 \mathrm{nmol} \mathrm{L}^{-1}$, but in hatchery $\mathrm{C}$ the highest $\mathrm{T} 3$ concentration was noted in May at $3.03 \mathrm{nmol} \mathrm{L}^{-1}$. T3 levels in the sea trout in the hatchery $\mathrm{C}$ recirculating systems gradually increased from January to April to $2.65 \mathrm{nmol} \mathrm{L}^{-1}$ and stabilized at $2.63 \mathrm{nmol} \mathrm{L}^{-1}$ in May. The correlation between T3 and fish weight, fork length, and CF was positive (Table 4). A consistent increase in $\mathrm{T} 4$ levels from

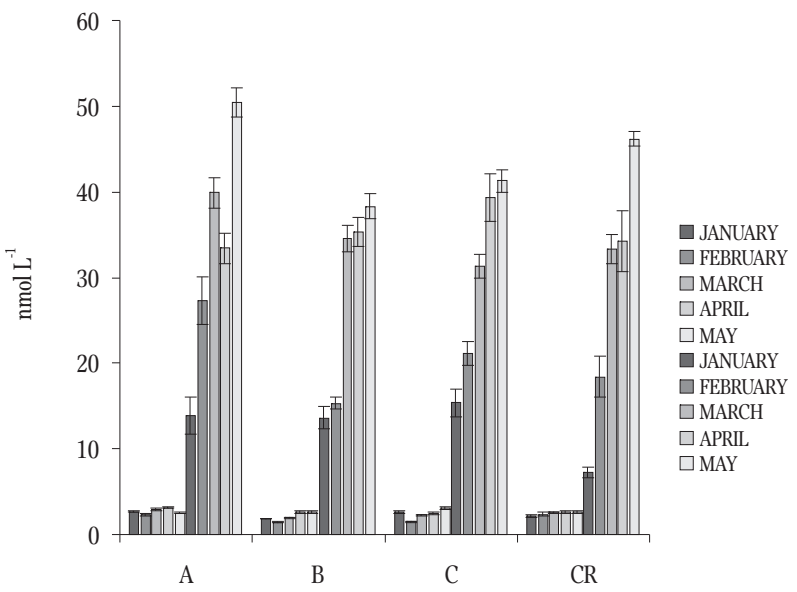

Figure 2. Changes in T3 concentrations in yearling sea trout ( $S$. trutta) during spring $\left(\mathrm{nmol} \mathrm{L}{ }^{-1}\right)$.
January until May was noted in the sea trout from all three hatcheries (Fig. 3) and in fish of different sizes from both types of rearing systems (Table 3). There was a slight decrease in T4 levels in hatchery A from March to April, but the highest T4 level was still noted in May. The T4 level was relatively low in January (7.20-15.37 $\left.\mathrm{nmol} \mathrm{L}^{-1}\right)$, but in May it reached 38.29-50.44 $\mathrm{nmol} \mathrm{L}^{-1}$ and even $90.87 \mathrm{nmol} \mathrm{L}^{-1}$ in hatchery $\mathrm{C}$ flow-through systems. No correlations were noted between $\mathrm{T} 4$ and fish weight, fork length, or CF (Table 4). Overall, the degree of silvering depended significantly on fish fork length $\left(\mathrm{r}^{2}=0.427, \mathrm{P}\right.$

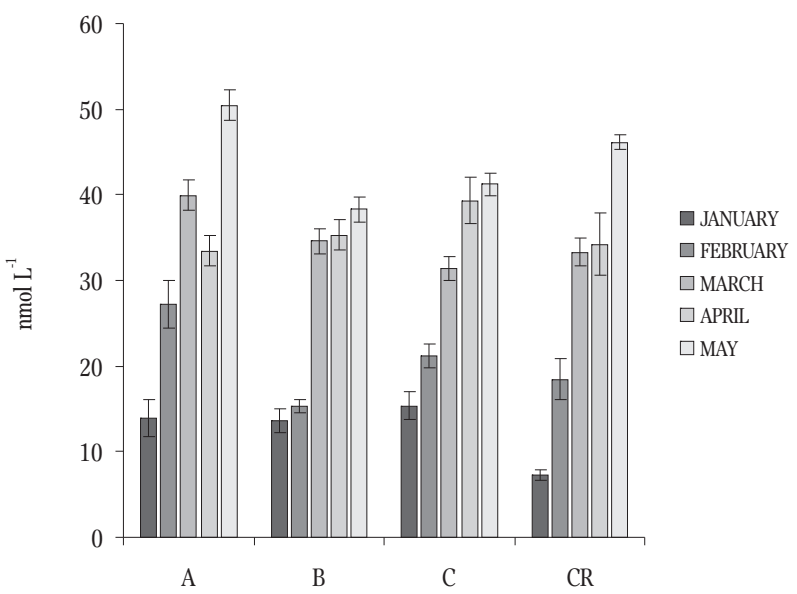

Figure 3. Changes of T4 concentrations in yearling sea trout ( $S$. trutta) during spring $\left(\mathrm{nmol} \mathrm{L}^{-1}\right)$. 
Table 4

Correlation between body weight $(\mathrm{g})$, fork length $(\mathrm{cm})$, condition factor $(\mathrm{CF})$, triiodothyronine $(\mathrm{T} 3)$ and thyroxine $(\mathrm{T} 4)$ parameters $(\mathrm{n}=386)$

\begin{tabular}{|c|c|c|c|c|c|}
\hline & Weight & Fork length & $\mathrm{CF}$ & Silvering level & T3 \\
\hline Weight & - & & & & \\
\hline Fork length & $0.936^{*}$ & - & & & \\
\hline $\mathrm{CF}$ & $0.180 *$ & -0.132 & - & & \\
\hline Silvering level & $0.398 *$ & 0.427 * & -0.038 & - & \\
\hline T3 & 0.311 * & $0.268^{*}$ & $0.157^{*}$ & $0.440^{*}$ & - \\
\hline $\mathrm{T} 4$ & 0.061 & 0.062 & -0.010 & $0.448 *$ & $0.305^{*}$ \\
\hline
\end{tabular}

* - significant correlations at $\mathrm{P}<0.05$

$<0.05)$, T3 level $\left(\mathrm{r}^{2}=0.440, \mathrm{P}<0.05\right)$, and T4 level $\left(\mathrm{r}^{2}=0.448, \mathrm{P}<0.05\right)$, but it was not dependent on $\mathrm{CF}\left(\mathrm{r}^{2}=-0.038, \mathrm{P}<0.05\right)$ (Table 4).

\section{Discussion}

Our results indicate that $\mathrm{T} 4$ increases in all the sea trout examined were independent of fish size, whereas T3 was higher in fish with longer fork lengths, greater weights, and higher $\mathrm{CF}$. The results of previous research on Atlantic salmon (McCormick et al. 2014) indicated that the minimum fork length for becoming a smolt is $14 \mathrm{~cm}$. Quigley et al. (2006) report that the mean T4 level in two-year-old sea trout smolts was $93 \mathrm{nmol} \mathrm{L}^{-1}\left(37 \mathrm{ng} \mathrm{mL}^{-1}\right)$. In light of this, the current study confirmed that thyroid hormone levels increased in spring, but the levels were insufficient for the fish to be classified as smolts.

Although it has been reported that sea trout exhibit fewer visual signs of smoltification than do other salmonids (Quigley et al. 2006, Dębowski et al. 2010), it is most likely sea trout parrs with no or insignificant visual signs of smoltification and low weights but raised thyroid hormone levels are not smolts. Munakata et al. (2014) report that plasma T4 levels in yearling masu salmon (Oncorhynchus masou) smolts were higher than those of one-year-old parrs. It is possible that the situation with sea trout could have been similar. However, during our research there were no significant differences in thyroxine levels between smaller and larger sea trout even in hatchery $\mathrm{C}$, where $\mathrm{T} 4$ levels were the highest in May. On the other hand, Quigley et al. (2006) report that yearling Atlantic salmon (Salmo salar) could exhibit a clear increase in seawater tolerance without elevated T4 levels. Nevertheless, in the same research T4 levels in two-year-old Atlantic salmon and sea trout had distinct T4 concentration surges that coincided with the highest hypo-osmoregulatory ability.

The analysis of average characteristic values for different degrees of silvering indicated that there is a positive correlation between the degree of silvering and fish length and T3 and T4 levels, which were noted in both types of rearing systems. This confirms previous research by Hoar (1988), who reports that thyroid hormones affect skin pigmentation and that the disappearance of melanin and deposition of guanine also happen because of increased thyroid hormone levels. There were no correlations between the degree of silvering and $\mathrm{CF}$, which is consistent with the research of Dębowski et al. (1999) that showed that $\mathrm{CF}$ is useless as a smoltification indicator. However, Quigley et al. (2006) found that the CFs of oneand two-year-old Atlantic salmon decreased during the parr-smolt transformation period, but the CFs of two-year-old sea trout during smoltification 
increased. In the present study, CF did not change significantly from winter to spring. The results of the present study do not correspond to those of the research by Ojima and Iwata (2009), which showed that the rise in chum salmon (Onchorhynchus keta) thyroid hormones was caused by migration. The present study detected increased thyroid hormones in sea trout of different sizes that were kept in tanks and that were not migrating at that time they were examined.

Water temperature in recirculating systems affected fish feeding and growth, while there was no clear evidence that water temperature positively affected smoltification. Because of the higher water temperatures, sea trout from the recirculating systems were larger than those from the flow-through systems. Nevertheless, the fish from the recirculating systems did not exhibit the clear signs of smoltification (degree of silvering 4, significantly higher thyroid hormone levels) that could be expected. Only a few individuals achieved the highest degree of silvering, and the thyroid hormone levels were only slightly higher than those in the fish from the flow-through systems. Relatively high water temperatures in the recirculating systems facilitated more intense sea trout feeding and faster growth. The high CI values even led us to consider that sea trout in the recirculating systems were overfed. During smoltification, wild Atlantic salmon experience significant decreases in CI (Wedemeyer et al. 1980). Wild smolts have lower body lipid levels and lower body weights than parrs (Jonsson and Jonsson 2003, Stefansson et al. 2003). Earlier studies show that feeding affects smoltification. For example, Olsson et al. (2001) showed that feed availability had a strong impact on the initiation of smolt migration, i.e., low levels of available feed induced migration. Several studies have shown that migratory behavior can be promoted by manipulating feed availability and the energetic state of fish and that reduced feed quantities during the last months before release enhanced migratory behavior and smolting (Lans et al. 2011, Larsson et al. 2012, Vainikka et al. 2012, Davidsen et al. 2014, Jones et al., 2015). However, food restriction in late fall can delay smoltification (Näslund et al. 2015). This means that feed rations and quality must be considered in fish hatcheries, and future research must be done to designate optimal feed amounts to promote smoltification.

The conclusion from the current research is that changes in thyroid hormone levels cannot be evaluated separately from other signs to determine smoltification. Increased thyroid hormone levels were noted in yearling sea trout of different sizes during spring. Although sea trout reared in recirculating systems were larger and exhibited signs of smoltification earlier than sea trout reared in flow-through systems, by the time of release in May the sea trout from all the hatcheries had nearly equal thyroid hormone levels.

Acknowledgements. The authors express their thanks to M. Zingis, who contributed greatly to the study through his laboratory work.

Author contributions. I.R. performed the research, analyzed data, and wrote the paper; R.M. planned, designed and organized the research, wrote the paper.

\section{References}

Berrill I.K., Porter M.J.R., Bromage N.R. 2006 - The effects of daily ration on growth and smoltification in $0+$ and $1+$ Atlantic salmon (Salmo salar) parr - Aquaculture 257: 470-481.

Birt T.P., Green J.M. 1986 - Parr-smolt transformation in female and sexually mature male anadromous and nonanadromus Atlantic salmon, Salmo salar - Can. J. Fish. Aquat. Sci. 43: 680-686.

Birzaks J., Peslaks J., Urtāns Ē., Aleksējevs Ē. 1997 Piekrastes un iekšējo ūdeņu zivis - In: Latvijas zivsaimniecības gadagrāmata 1996/97 (Ed.) N. Riekstiņš, Zivju fonds, Riga: 135-160.

Björnsson B.T., Stefansson S.O., McCormick S.D. 2011 Environmental endocrinology of salmon smoltification Gen. Comp. Endocr. 170: 290-298.

Davidsen J.G., Daverdin M., Sjursen A.D., Rønning L., Arnekleiv J.V., Koksvik J.I. 2014 - Does reduced feeding prior to release improve the marine migration of hatchery brown trout Salmo trutta smolts? - J. Fish Biol. 85: 1992-2002. 
Dębowski P., Glogowski J., Robak S., Dobosz S. 1999 Smoltification of hatchery-reared Atlantic Salmon (Salmo salar L.) - indices and methods of estimation Arch. Pol. Fish. 7: 267-279.

Dębowski P., Dobosz S., Grudniewska J., Kuzminski H. 2010 - Possibilities of using the length differentiation of hatchery sea trout, Salmo trutta L., parr to predict numbers of one-year smolts - Arch. Pol. Fish. 18: 51-58.

Dickhoff W.W., Folmar L.C., Gorbman A. 1978 - Changes in plasma thyroxine during smoltification of coho salmon, Oncorhynchus kisutch - Gen. Comp. Endocr. 36: 229-232.

Ebbesson L.O.E., Ekstrom P., Ebbesson S.O.E., Stefansson S.O., Holmqvist B. 2003 - Neural circuits and their structural and chemical reorganization in the light-brain-pituarity axis during parr-smolt transformation in salmon - Aquaculture 222: 59-70.

Ebbesson L.O.E., Bjornsson B.Th., Ekstrom P., Ebbesson S.O.E., Stefansson S.O. 2008 - Daily endocrine profiles in parr and smolt Atlantic salmon - Comp. Biochem. Physiol A 151: 698-704.

Ebbesson L.O.E., Nilson T.O., Helvik J.V., Tronci V., Stefansson S.O. 2011 - Corticotropin-releasing factor neurogenesis during midlife development in salmon: genetic, environmental and thyroid hormone regulation J. Neuroendocrinol. 23: 733-741.

Folmar L.C., Dickhoff W.W. 1980 - The parr-smolt transformation (smoltification) and seawater adaptation in salmonids: A review of selected literature - Aquaculture 21: 1-37.

Griffith R.W. 1974 - Pituitary control of adaption to fresh water in the teleost genus Fundulus - Biol. Bull. 146: 357-376.

Hoar W.S. 1988 - The physiology of smolting salmonids - In: Fish Physiology, Volume 11B (Eds.) W.S. Hoar, D.J. Randall, Academic Press, New York: 275-343.

Holzer G., Laudet V. 2015 - Thyroid Hormones: A Triple-Edged Sword for Life History Transitions - Curr. Biol. 25: 344-347.

Jones D.A., Bergman E., Greenberg L.A. 2015 - Food availability in spring affects smolting in brown trout (Salmo trutta) - Can. J. Fish. Aquat. Sci. 72: 1649-1699.

Jonsson N., Jonsson B. 2003 - Energy density and content of Atlantic salmon: variation among developmental stages and types of spawners - Can. J. Fish. Aquat. Sci. 60: 506-516.

Katz A.H., Katz H.M. 1978 - Effects of DL-thyroxine on swimming speed in pearl danio Brachydanio albolineatus (Blyth.) - J. Fish Biol. 12: 527-530.

Lans L., Greenberg L.A., Karlsson J., Calles O., Schmitz M., Bergman E. 2011 - The effects of ration size on migration by hatchery-raised Atlantic salmon (Salmo salar) and brown trout (Salmo trutta) - Ecol. Freshw. Fish. 20: 548-557.
Larsson S., Serrano I., Eriksson L.O. 2012 - Effects of muscle lipid concentration on wild and hatchery brown trout (Salmo trutta) smolt migration - Can. J. Fish. Aquat. Sci. 69: 1-12.

Medne R. 2011 - Research of clinical signs and etiological factor of salmon fin necrosis, PhD thesis, Jelgava: $125 \mathrm{p}$.

McCormick S.D., Björnsson B.T. 1994 - Physiological and hormonal differences among Atlantic salmon parr and smolts reared in the wild, and hatchery smolts Aquaculture 121: 235-244.

McCormick S.D., Björnsson B.T., Sheridan M., Eilerson C., Carey J.B., O’Dea M. 1995 - Increased daylength stimulates plasma growth hormone and gill $\mathrm{Na}+, \mathrm{K}+$-ATPase in Atlantic salmon (Salmo salar) - J. Comp. Physiol. 165: 245-254.

McCormick S.D. 2013 - Smolt physiology and endocrinology - In: Euryhaline Fishes, Fish Physiology, Volume 32 (Eds.) S.D. McCormick, A.P. Farrell, C.J. Brauner, Academic Press, Amsterdam: 199-251.

McCormick S.D., Haro A., Lerner D.T., O’Dea M.F., Regish A.M. 2014 - Migratory patterns of hatchery and stream-reared Atlantic salmon Salmo salar smolts in the Connecticut River, U.S.A. - J. Fish Biol. 85: 1005-1022.

Munakata A., Miura G., Matsuda H. 2014 - Evaluation of seasonal and daily changes of plasma thyroxine and cortisol levels in wild masu salmon Oncorhynchus masou, samples by a Japanese fishing method - J. Fish Biol. 85: 1253-1262.

Näslund J., Sundström L.F., Johnsson J.I. 2017 - Autumn food restriction reduces smoltification rate, but not over-winter survival, in juvenile brown trout Salmo trutta - Ecol. Freshw. Fish. 26: 205-216.

Ojima D., Iwata M. 2009 - Central administration of growth hormone-releasing hormone triggers downstream movement and schooling behavior of chum salmon (Onchorhynchus keta) fry in an artificial stream - Comp. Biochem. Physiol. 152: 293-298.

Olsson I.C., Greenberg L.A., Eklov A.G. 2001 - Effect of an artificial pond on migrating brown trout smolts - N. Am. J. Fish. Manage. 21: 498-506.

Osborn R.H., Simpson T.H., Youngson A.F. 1978 - Seasonal and diurnal rhythms of thyroidal status in the rainbow trout, Salmo gairdneri Richardson - J. Fish Biol. 12: 531-540.

Quigley D.T.G., Harvey M.J., Hayden T.J., Dowling C., O’Keane M.P. 2006 - A comparative study of smoltification in sea trout (Salmo trutta L.) and Atlantic salmon (Salmo salar L.): seawater tolerance and thyroid hormone titres - Biology and Environment: Proceedings of the Royal Irish Academy, 106: 35-47.

Rutkovska I., Medne R. 2015 - Morphological changes in artificially reared one year old sea trout (Salmo trutta L.) during spring - Research for Rural Development. Annual $21^{\text {st }}$ International Scientific Conference proceedings, Vol. 
1, Jelgava 13-15.05.2015, Latvia University of Agriculture, Jelgava: 189-193.

Soivio A., Muona M., Virtanen E. 1989 - Smolting of two populations of Salmo trutta - Aquaculture 82: 147-53.

Sokal R.R., Rohlf F.J. 2000 - Biometry: the principles and practice of statistics in biological research (3rd ed.) W.H. Freeman and company, New York, 879 p.

Stefansson S.O., Bjornsson B.T., Sundell K., Nyhammer G., McCormick S.D. 2003 -Physiological characteristics of wild Atlantic salmon post-smolts during estuarine and coastal migration - J. Fish Biol. 63: 942-955.
Vainikka A., Huusko R., Hyvarinen P., Korhonen P.K., Laaksonen T., Koskela J., Vielma J., Hirvonen H., Salminen M. 2012 - Food restriction prior to release reduces precocious maturity and improves migration tendency of Atlantic salmon (Salmo salar) smolts - Can. J. Fish. Aquat. Sci. 69: 1981-1993.

Wedemeyer G.A., Saunders R.L., Clarke W.C. 1980 - Environmental factors affecting smoltification and early marine survival of anadromous salmonids - Mar. Fish. Rev. 42: 1-14.

Zydlewski G.B., Stich D.S., McCormick S.D. 2014 Photoperiod control of downstream movements of Atlantic salmon Salmo salar smolts - J. Fish Biol. 85: 1023-1041. 